3. Vysotskyy O. Technologies and strategies of language policy. O. Vysotsky. Social and humanitarian research and innovative educational activity. Materials of the International Scientific Conference. May 24-25. 2019. The city of Dnipro. Science edit O.Yu.Vysotskyy. Dnipro. SPD "Okhotnik". 2019. P. 68-71.

4. Vysotskyy O. Theoretical and Methodological Measurements of Language Policy. O. Vysotskyy. PhilosophicalWorldview and Cultural Contexts of Continuing Education: Materials of the International Scientific and Practical Conference. April 12-13. 2019. The city of Dnipro. The "DANO" DOR ". Science edit O.E. Vysotska. Dnipro: SPD "Okhotnik", 2019. P. 138-140.

5. Diyak I. Ukrainian revival or new Russification ?: Scientific publication. - K.: Granoslov, 2000. - 304 pp.

6. Zamkova N. Projects on the implementation of "interlanguage relations" and language policy within the limits of utopian projects of modern Ukraine. N. Zamkova. Time of choice: challenges of the information age: collective monograph per comp. edit O. A. Yakovleva. Odessa. Publishing House "Helvetica". 2016. P. 54-66.

7. Masenko L. Bilingual Danger. Ukrainian lesson. 2005. No. 3-4. P. 3-4.

8. Gorbatenko V. Postmodern and transformation of the value basis of human existence. V. Gorbatenko. Political Management. Kyiv. 2005. №1. P. 3 - 13.

9. Ostapenko M. Political pluralism as a value basis of a democratic society: Author's abstract. dis ... doc. flight. Sciences: 23. 00. 03. National Pedagogical University named after M. P. Drahomanov. Kyiv. 2013. - 36 p.

10. Political and ideological process in the Ukrainian society under modernization: comparative analysis. [Monograph]. For co. edit FM Rudich. K. IMIDEND them. I.F. Kuras National Academy of Sciences of Ukraine. 2013. $448 \mathrm{p}$.

11. Postol A. Postmodernism as a modern socio-political reality. A. Postol. Humanitarian Bulletin ZGIA. Zaporozhye. Vip. 42. 2010. P. 69-79.

12. Ruda O. The Language Question as an Object of Manipulating Strategies in the Contemporary Ukrainian Political Discourse: Monograph. Olena Ruda. NAS of Ukraine. Institute of Ukr. Language. K. 2012. - 232 p.

13. Savoyska S. The communicative aspect of the language policy of regional development and territorial integration in the context of globalization (on an example of decentralization of Ukraine). Time of choice: challenges of the information age: collective monograph. per colleagues. edit O. A. Yakovleva. Odesa. Publishing House Helvetyka. 2016. P. 372-385.

14. Savoyska S. On the policy of decentralization with the Russian "taste" (on the example of the language policy of modern Ukraine). Problems of modernization of Ukraine. [SB. sciences etc.]. Materials Allukr. sciences - practice conf. IAPM "European Dimension of Reforming Public Administration in Ukraine". Red. M. N. Kurko (head) [and others]. K. DP "Publishing House" Personnel". Vip November 3 - 24. 2016. P. 126-129.

15. Sivak T. Delitiable Democracy as the Basis for Strategic Communications in Ukraine. T. Sivak. Res Politicae. The academy im Jan Dlugosza w Częstochowie. 2017. Vol. 19. P. 95-102.

16. Stepanova N., Andrienko Y. Political participation in the postmodern age. Ukrainian practice. N. Stepanova, Yu. Andrienko. Young scientist. No. 5 (20). Part 4. May 2015. P. 125-128.

17. Tanchyn I. Ukrainian Right-wing Radical Party Following the Revolution of Dignity. Igor Tanchyn. Galyna Lutsyshyn. Humanitarian Vision. 2016. Volume 2. Number 2. P. 43-48.

18. Thoma N. Visualization as a characteristic of postmodern political action. N. M. Khoma. Gilea. Political science. Collection of scientific works. 2014. No. 89. P. 405-408.

19. Chernysh A. Language and Identity in the Modern World. Language and Society. Lviv University I. Franca. 2012. Voice. 3. P. 13-22.

DOI 10.31558/2617-0248.2019.4.14

УДК 321.7:316.32.383

\title{
ТЕКСТИ ОФІЦЙНОГО ПОЛІТИЧНОГО ДИСКУРСУ ЯК ІНДИКАТОР ЕВОЛЮЦІї ПОЛІТИЧНОГО РЕЖИМУ (НА МАТЕРІАЛІ ПРОМОВ УКРАЇНСЬКИХ ПРЕЗИДЕНТІВ)
}

ORCID ID: https://orcid.org/0000-0001-9799-9786

Стеблина Н. О. к. н. соц. коммун., доцент, докторантка кафедри політології та державного управління Донецького національного університету імені Василя Стуса (Україна)

В українському науковому дискурсі промови політиків більше вивчаються з точки зору політичної лінгвістики, до уваги беруться здебільшого тексти зарубіжних політиків. До того ж, для вивчення промов найчастіше застосовуються якісні методи, що унеможливлює відслідковувати динаміку політичних процесів за тривалі періоди часу.

У статті на матеріалі 856 промов українських президентів: Ющенка, Януковича та Порошенка (за увесь період правління) із застосуванням формалізованого методу аналізу демонструється коливання параметрів політичних текстів залежно від зміни режиму.

Висувається гіпотеза про більш інтенсивну та різноманітну (у жанровому плані, планах форматів, інформаційних приводів, аудиторій, географії) комунікацію, притаманну більш демократичним режимам 
Ющенка та Порошенка. Перша частина гіпотези про більш інтенсивну комунікацію (за простим кількісним підрахунком промов) за часів Януковича підтвердилася лише частково - за два перші роки правління. Друга частина гіпотези підтвердилася.

За часів Ющенка та Порошенка використовувалися не лише основні жанри прямих звернень до аудиторії (промови, виступи, слова, звернення, заяви), але й більша кількість піджанрів. При цьому у статті зауважується, що основні жанри прямих звернень лишаються недостатньо вивченими у царині політичних наук.

Для виголошення промов третім та п'ятим президентами України створювалося більше різноманітних та унікальних форматів заходів (усього 29 та 39 позицій відповідно; 18 позицій у Януковича). Також інформаційні приводи їхніх прямих звернень були більш пов'язані із поточними подіями, ніж із календарними та історичними подіями. У той час як промови Януковича були менш різноманітними за згаданими уних форматами та частіше були викликані календарними та історичними приводами (58,7\% історичних та календарних у Януковича, 46,3\% у Ющенка, 44,9\% у Порошенка).

Щодо аудиторій, можемо констатувати наявність однакових найбільш популярних аудиторій для усіх трьох політиків (народ, міжнародні інститути, парламент). Тим не менш, різниця відчувається у різному розподілі уваги до них та у більшій кількості згадок про аудиторії у демократичних лідерів. Географічні преференції дозволяють нам показувати різну спрямованість щодо міжнаціональних блоків (Західні країни для демократичних лідерів, країни СНД для Януковича), а також зафіксувати більшу увагу до регіонів у межах країни, ніж до зарубіжних країн, та до країн із авторитарними режимами відповідно у авторитарного лідера.

Ключові слова: політичний режим, політична промова, жанри політичних промов, аудиторії політичних промов, президенти України

Steblyna N. O., Official political discourse texts as an indicator of the political regime evolution (by the mean of speeches of Ukrainian presidents)

In Ukrainian scientific discourse politics' speeches are predominantly studied within political linguistic. Primarily scholars pay their attention at foreign politician speeches. Additionally, qualitative methods are usually used, and there is almost impossible to measure political processes' dynamics for large periods of time.

In the paper 856 speeches of Ukrainian presidents (Yuschenko, Yanukovych, Poroshenko) are studied - all the speeches for the whole period of presidency. With the formal analysis oscillations of different parameters in the political texts, due to changes of political regimes is demonstrated.

The main hypothesis of the study is the interrelation between more intense and diverse (in the terms of genres, formats of events, informational occasions, audiences, geography) communication and more democratic regime. The first part of the hypothesis was partly approved. Simple count of the quantity of the speeches shows, that low intensity of speeches was observed only during the first two years of Yanukovych presidency. The second part of the hypothesis was approved.

Yuschenko's and Poroshenko's speechwriters used not only main genres of speeches (statements, appeals and etc), but subgenres as well. Additionally it is stressed, that in the Ukrainian scientific tradition genres of direct appeals aren't studied enough.

The third and the fifth Ukrainian presidents' teams created more diverse and unique actions formats (29 and 39 respectively; 18 for Yanukovych). Information occasions were mostly connected with current affairs, whereas in the Yanukovysh case historical and calendar occasions prevailed $58,7 \%$ historic and calendar occasions for Yanukovych, 46,3\% Yuschenko, 44,9\% Poroshenko).

As for audiences, there are three the most popular recipients for all the presidents (people, international institutions, and parliament). However, the difference is in the attention distribution and the bigger number of audiences mentions in democratic leaders' speeches. Geographic names mentions analysis shows different approaches towards international blocks (the Western countries and more democratic countries for the democratic leaders; the CIS countries and more authoritative countries for Yanukovych).

Key words: political regime, political speech, genres of political speeches, audiences of political speeches, Ukrainian presidents

В українській науковій традиції політичні промови переважно вивчаються з точки зору вживання у них певних мовних засобів та стилістики. До того ж, об’єктом вивчення зазвичай стають один чи декілька текстів, оскільки вітчизняні дослідники використовують якісні методи для аналізу. Тим не менш, політичні промови становлять інтерес не тільки для політичної лінгвістики, але й можуть активніше вивчатися як тексти, через які «промовляє» політичний устрій. Відтак, саме у політичних промовах можна фіксувати зміни політичного режиму, і потенційно - прогнозувати такі зміни. Окрім того, використання кількісних методів або ж поєднання кількісних та якісних методів аналізу промов дасть змогу охопити більший корпус текстів і показати політичний процес у його динаміці - через аналіз інтенсивності промов, їхніх інформаційних приводів, комунікативних ситуацій, аудиторій та ін.

Ця стаття є спробою саме такого дослідження, матеріалом якого стали більш ніж 800 промов українських президентів: Ющенка, Януковича та Порошенка. 3 нашої точки зору політичні тексти, до яких ми уналежнюємо 
промови, є «дзеркалом» політичного режиму, відтак зміни режиму відбиваються на текстах. Метою цього дослідження буде через формальний аналіз заголовків промов трьох українських президентів показати зміни у політичному режимі країни. В результаті буде встановлено, за якими показниками можна визначати перехід від демократичного режиму до авторитарного і навпаки: від авторитарного до демократичного. Основною гіпотезою дослідження $є$ зв'язок між тяжінням режиму до авторитаризму та меншою різноманітністю використовуваних спікером піджанрів, інформаційних приводів, комунікаційних ситуацій та типів аудиторій.

Рівень політичних та громадських свобод за цих трьох українських президентів зазнавав значних коливань. За оцінками різних міжнародних правозахисних організацій, таких як Freedom House, IREX, за часів Януковича, рівень свобод в країні знизився. При цьому Україна не потрапила до переліку не вільних (anti-free / not free) країн, де перебувають, приміром, Росія та Білорусь, однак, за показником свободи слова за Ющенка та Порошенка Україна мала 2 та 2,09 пунктів (із 4), за Януковича - 1,84 у 2011 та 1,66 у 2014 (дані IREX*). Згідно із доповідями Freedom House, у 2010 році країна мала статус вільної із 2,5 пунктами (де 1 - найкраща ситуація, 7 - найгірша). У 2013-2014 оцінки знизилися до 3,5, а статус - до частково вільної. За Порошенка Україна мала трохи вищу оцінку 3, тим не менш, статус вільної так і не отримала**.

Обидві організації Freedom House та IREX користуються для укладення своїх звітів експертними оцінками, тим часом як формальний аналіз політичних текстів дасть змогу отримати більш повну та об'єктивну картину і підтвердити або спростувати спостереження, отримані міжнародними правозахисниками.

\section{Політичні промови як об'скт вивчення}

Незважаючи на доволі значну кількість наукових публікацій, матеріалом вивчення для яких стали політичні промови, все ж царину українського спічрайтингу не можна назвати достатньо вивченою. Переважна більшість досліджень, яку знаходимо в електронному каталозі Національної бібліотеки України імені В. Вернадського стосується саме лінгвістики. Зокрема, вивчаються мовно-стилістичні ознаки [8], семантичні особливості функціонування фразеологізмів у політичному дискурсі [6] лексичні та стилістичні, лінгвостилістичні та гендерні особливості цього типу текстів. Цікаво, що в основному, у політичній лінгвістиці дослідники спираються на аналіз промов саме іноземних політиків.

Окрім того, політичні промови вивчаються з точки зору їхнього впливу на свідомість аудиторії, зокрема через маніпулювання [13], параноїдну акцентуацію політичного діяча [7], або через формування у реципієнтів відповідної картини світу [14]. У цьому аспекті використовується також дискурс-аналіз, таким чином «розкриваються приховані значення... у промовах та визначається, які саме знання та вірування спікер хотів би сформувати у своєї аудиторії, при цьому описуються також «риторичні стратегії» [18; 20]. Також розглядається проблема впливу супра- і топографематичних засобів на виголошення промови [15].

Додатковим свідченням недостатньої вивченості політичних промов є доволі широкі визначення для цього типу політичного тексту, а також відсутність розробленої класифікацій політичних промов.

Наприклад, А. Худолій визначає політичну промову і як «форму публічного виступу» і як «процес комунікації і один з видів соціальної дії» [14, с. 208]. Тим не менш, нас промова цікавить саме як форма, що зумовлює відповідний зміст.

На думку А. Гузак, яка вивчала президентські промови, це «офіційний публічний виступ глави держави з позитивними чи негативними оцінками, обгрунтуваннями, конкретними фактами, окресленими планами, перспективою політичних змін. Такий виступ характеризується емоційністю, чіткістю постановки проблем, насиченістю, конкретністю, дієвістю, а також стислими часовими межами» [2, с. 57]. Тим не менш, публіцистичні тексти на політичну тематику також можуть мати схожі складові (оцінки, обгрунтування, факти, плани, перспективи) та ознаки (емоційність, насиченість, дієвість та ін.). Тож виходить, що єдиною жанроутворюючою ознакою промови $є$ тільки те, що його виголошує політик.

Дж. Хабве більш звужує визначення, додаючи, що це саме монологічний текст (бо часом до промов уналежнюють дебати між політиками (див [17]), а також визначає мету промови «просувати питання, що стосуються управління державою чи то прямо, чи то непрямо». На думку дослідника, промова - це піджанр політичного дискурсу; також промова відбувається у межах політичної події [19, с. 5]. Тобто промова сама по собі не є дією, як-от стверджує А Худолій, а є, швидше, пов'язаною із нею або є викликаною певною подією. Цей факт, на нашу думку, і відбивається на намаганнях дослідників виокремлювати певні підтипи промов, виходячи із комунікативної ситуації, якою вони були породжені, наприклад, новорічна політична промова [11] або передвиборча промова [3].

Ще один аспект, який ускладнює жанрову диференціацію промов,- вплив на процес їнього створення самих спікерів-політиків, найбільше уваги цьому питанню присвячують російські дослідники (див [4; 5; 10; 12]).

Тим не менш, політична практика дає нам приклад зовсім іншої класифікації промов президентів. Якщо взяти до уваги сайт Президента України, то там у розділі «промови» знаходимо не тільки власне «промови», але й виступи, заяви, звернення, послання, коментарі та ін. Звісно, практика використання жанру завжди випереджала теорію, тим не менш, цілком очевидною $є$ потреба детальніше визначити та описати як сам жанр промови (припускаємо, що це саме родове поняття у цьому плані), так й інші жанри, які використовуються президентами. Важливими для визначення можуть стати якраз «політичні події», які ці типи текстів породжують. Приміром, промова може бути справді «монологічним» форматом, а от виступ, ймовірно, передбачає наявність інших виступів на певному заході, тож має бути укладений відповідно до комунікативних інтенцій інших мовців, містити відсилки до них та ін. 
Відтак, можемо зробити висновок, що політичні промови саме уцарині політичних наук потребують детальнішого вивчення, зокрема в аспекті відображення у них поточної політичної ситуації та поточного політичного режиму (приміром, для судових промов укладено жанрову типологію (див. [16]). У подібному ракурсі цей тип текстів ще не розглядався. В цілому, політичні промови детально описані у царині політичної лінгвістики, переважно на матеріалі текстів іноземних політиків. Тому в цьому плані промови вітчизняних діячів також заслуговують на більш прискіпливий інтерес. Окремою проблемою тут $є$ також відсутність визначень політичних промов як конкретного жанру та інших жанрів прямих звернень до аудиторії, що створюються як реакція на конкретну політичну подію.

\section{Матеріал дослідження та формальний аналіз промов президентів}

Особливістю наповнення офіційного сайту президента, що $\epsilon$ основним джерелом промов, $\epsilon$ те, що наступники завжди видаляють увесь контент попередника. Цілком зрозумілим є те, що зміна президента може означати зміну політичного курсу, а отже й зміну комунікативних пріоритетів. Тим не менш, приміром, на офіційному сайті польського президента усі тексти, у тому числі промови, попередників переміщаються в архів, а сам сайт наповнюється новою командою. Про важливість формування архіву президентських промов говорять і А. Баровська та I. Коваль, зазначаючи деяку недосконалість комунікації між президентом та суспільством в Україні: «факт оприлюднення як [разове] доведення інформації до відома населення, зокрема у спосіб опублікування, та можливість надання президентських документів (матеріалів) не вичерпує задоволення вимоги щодо обов'язку держави створити умови для реалізації доступу до публічної інформації, що відрізняє право на доступ до інформації від права на інформацію» [1, с. 14].

На сьогодні промови президентів в електронному вигляді доступні читачам тільки через веб архів Way back machine (http://web.archive.org/), який також містить пробіли (тижневі або й навіть у декілька місяців), тож припускаємо, що 856 текстів промов, які було знайдено із його допомогою, - це не весь корпус текстів. Тим не менш, ця кількість все ж дає нам підстави сподіватися на репрезентативність нашого дослідження, оскільки пробіли у рубриці «промови» заповнювалися із допомогою рубрики «новини», підрубрикою якою $є$ «промови». Окремі тексти також можна знайти на сайтах 3МI та інших веб-ресурсах.

У знайдених промовах ми визначали:

- Інтенсивність створення промов (через дату публікації)

- Жанрове визначення (жанр прямого звернення найчастіше вказується у назві, ті промови, що не містили такого визначення, розподілялися у категорію «без жанру)

- Географію промов (через вказані географічні назви країн або населених пунктів)

- Формат заходу, під час якого промови виголошувалися (через вказані у назвах формати)

- Нагоду або інформаційний привід (через вказані у назвах нагоди), окремо ми розглядали т. зв. історичні та календарні нагоди: відзначення історичних дат, свят або «днів»

- Аудиторію (через вказані у назвах інститути або суспільні групи, до яких звертався президент).

Для того, щоб формалізувати аналіз, використовувався словник жанрів промов президентів, а також словник географічних назв. Наявність у назві промови формату заходу визначалась через прийменники «на», «під час», «при», «за підсумками», «за результатами», «після». Приміром:

- Промова Президента України під час церемонії інавгурації

- Виступ Президента на урочистому зібранні з нагоди 70-ї річниці визволення Києва від фашистських загарбників

Вказання у промові інформаційного приводу визначалось через прийменники «щодо», «у зв’язку з», «з приводу», «стосовно», «напередодні», «з нагоди». Наприклад:

- Звернення Президента з приводу останніх подій у Києві

- Звернення Президента України з нагоди Дня Гідності та Свободи

Історичні та календарні нагоди знаходилися через іменники «день», «меморіал», «монумент» (в усіх відмінках та у множині), корені «-річ», «рок», корені, префікс та суфікс «вшануван».

Аудиторія промов визначалася через прийменники «до», «у», «перед», «для», «з», «на».

Результати дослідження

Інтенсивність промов

Простий кількісний підрахунок промов на сайтах президентів таких авторитарних держав, як Білорусь та Казахстан, показує низьку інтенсивність публічних виступів президентів цих країн порівняно з Україною. Приміром, річна кількість промов президента Казахстану Назарбаєва коливається від 8 до 19, президента Білорусі Лукашенка від 13 до 15. На основі цих даних можна було б припустити, що низька інтенсивність офіційної комунікації між президентом та суспільством і його інститутами є характерною рисою авторитарних режимів, тож перехід країни до більш авторитарної моделі управління має характеризуватися зниженням кількості промов.

У таблиці 1 ми бачимо, що за кількістю промов Україна випереджає авторитарні режими, тим не менш, інтенсивність промов у Януковича та Порошенко приблизно однакова, якщо врахувати, що перший утік 3 країни до закінчення свого терміну. При цьому треба також врахувати декілька пробілів у даних за 2018 рік (в інтернетархіві відсутні дані від кінця липня 2018 до січня 2019, тим не менш частину промов було знайдено через розділ «новини»). 
Кількість промов президентів України 2005-2019

\begin{tabular}{|c|c|c|c|c|c|c|c|}
\hline \multirow{2}{*}{ Ющенко } & 2005 p. & 2006 p. & 2007 p. & 2008 p. & 2009 p. & 2010 p.* & ycboro \\
\hline & 72 & 62 & 70 & 63 & 65 & 7 & 339 \\
\hline \multirow{2}{*}{ Янукович } & 2010 p. & 2011 p. & 2012 p. & 2013 p. & 2014 p.** & - & \\
\hline & 33 & 46 & 78 & 65 & 6 & - & 228 \\
\hline \multirow{2}{*}{ Порошенко } & 2014 p. & 2015 p. & 2016 p. & 2017 p. & 2018 p. & 2019 p.*** & \\
\hline & 44 & 93 & 47 & 57 & 29 & 19 & 289 \\
\hline
\end{tabular}

* Промови за січень - до кінця президентського терміну

** Промови за січень-лютий - до втечі з країни

*** Промови за січень-травень - до кінця президентського терміну

Тож наше припущення про зв'язок між тяжінням режиму до авторитаризму та інтенсивністю промов підтверджується лише частково - у перші два роки правління Януковича. У 2012-2013 він вийшов на ту саму кількість, що й Ющенко. Схожість між Ющенком та Порошенком за цим показником спостерігається тільки у перші два роки (тут маємо взяти до уваги, що президентський термін Порошенка у 2014 почався у червні). Цікаво при цьому звернути увагу на те, що нинішній український президент також рідко комунікує із суспільством та його інститутами у форматі промов, за травень - листопад на сайті знаходимо сім промов. Тим не менш, висока інтенсивність промов на початку президентського терміну може свідчити про радикальну зміну курсу країни або ж, швидше, бажання про це заявити.

Інформаційні приводи

Оскільки простий підрахунок кількості промов лише частково підтверджує різницю між режимами, проаналізуємо додаткові параметри. Оскільки з нашої точки зору, авторитарний режим передбачає більший ступінь закритості влади, зокрема і в плані звернень голови держави до суспільства та його інститутів, цей факт має відображатися і на інформаційних приводах промов. Для того, аби це виміряти, ми поділили інформаційні приводи на історичні (відзначення певних історичних подій), календарні (відзначення свят (релігійних та світських) або ж днів (день боротьби зі СНІДом, день міліції та ін) та звичайні. Передбачаємо, що більш демократичний режим тяжітиме до переважання звичайних приводів над історичними та календарними, адже боротьба політичних сил та відносна свобода слова та думки має породжувати багато незапланованих подій та, відтак, вимагатиме спеціальної реакції зі сторони голови держави. Ця гіпотеза підтверджується: якщо вирахувати відсоток промов, присвячених історичним та календарним інформаційним приводам, то під час правління Януковича таких промов було більше $58,7 \%$, ніж за Ющенка (46,3\%) та Порошенка (44,9\%).

Жанрове визначення

Більш інтенсивна та невпорядкована (через вищу різноманітність інформаційних приводів) комунікація між головою держави та суспільством і його інститутами має відображатися й на використанні більш широкої жанрової палітри звернень. У таблиці 2 можна побачити співвідношення за цим параметром.

Отже, в цілому три українських президенти використовували усі основні жанри (звернення, виступи, слова, заяви та послання). Тільки Янукович не виступав із власне промовами. Тобто за цим параметром різниця мінімальна, однак, якщо ми звернемо увагу на використання піджанрів, вона стане виразнішою:

- Ющенко - чотири піджанри звернень (Янукович та Порошенко - один);

- Ющенко - чотири піджанри виступів (Янукович та Порошенко - жодного);

- Порошенко - один піджанр промов (Янукович та Ющенко - жодного);

- Порошенко - два піджанри послань (Янукович та Ющенко - жодного);

- Ющенко та Порошенко - три піджанри слів (Янукович - один);

- Ющенко та Порошенко - два піджанри заяв (Янукович - жодного).

Окрім цього, Ющенко і Порошенко запроваджують по одному власному жанру.

Можемо пояснити намагання уточнити жанр бажанням підкреслити особливість інформаційного приводу або ж нагоди: наприклад, «спільна заява» або «позачергове послання». Окрім того, у визначеннях піджанрів (це особливо характерно для Ющенка) бачимо виражену інтенцію до членування виступів («вступне звернення», «початок виступу», «заключний виступ»). Це можемо вважати бажанням структурувати комунікацію, задавати тон або ж підсумовувати сказане іншими.

Отже, виходячи із наявності більшої кількості піджанрів промов у Ющенка та Порошенка можемо констатувати більш урізноманітнену комунікацію між цими президентами та суспільством і його інститутами, ніж у випадку Януковича.

Формати заходів

На вибір жанру чи піджанру може впливати не тільки інформаційний привід, а й формат заходу, в якому бере участь спікер. Тож ми підрахували також і дані за цим параметром (див. табл. 3). 
Жанрові визначення промов президентів

\begin{tabular}{|c|c|c|c|}
\hline Жанри та піджанри & Ющенко & Янукович & Порошенко \\
\hline звернення & 116 & 99 & 100 \\
\hline новорічне звернення & 3 & 3 & 1 \\
\hline вступне звернення & 1 & & \\
\hline телевізійне звернення & 5 & & \\
\hline відеозвернення* & 1 & & \\
\hline усього звернень & 126 & 102 & 101 \\
\hline виступ & 109 & 88 & 147 \\
\hline початок виступу & 1 & & \\
\hline заключний виступ & 1 & & \\
\hline усього виступів & 111 & 88 & 147 \\
\hline промова & 30 & & 3 \\
\hline вітальна промова & & & 1 \\
\hline усього промов & 30 & 0 & 4 \\
\hline Слово & 16 & 4 & 6 \\
\hline вступне слово & 9 & 11 & 4 \\
\hline заключне слово & 3 & 1 & \\
\hline вітальне слово & 3 & 1 & \\
\hline усього слів & 31 & 17 & 10 \\
\hline Заява & 27 & 12 & 14 \\
\hline спільна заява & 5 & & 1 \\
\hline усього заяв & 32 & 12 & 15 \\
\hline послання & 2 & 3 & 2 \\
\hline позачергове послання & & & 1 \\
\hline щорічне послання & & & 1 \\
\hline усього послань & 2 & 3 & 4 \\
\hline відповідь на звернення & 1 & & \\
\hline коментар & & & 5 \\
\hline без жанру & 6 & 6 & 3 \\
\hline усього промов усіх & 339 & 228 & 289 \\
\hline
\end{tabular}

* Відсутність відеозвернень можемо пояснити розташуванням їх успеціальній рубриці за часів Януковича та Порошенка 
Вісник Донецького національного університету імені Василя Стуса, Сер.: Політичні науки • 2019

Таблиця 3

Формати заходів, на яких виголошувалися промови президентів

\begin{tabular}{|c|c|c|c|}
\hline & Ющенко & Янукович & Порошенко \\
\hline академія & 1 & 1 & \\
\hline акція & 1 & & 3 \\
\hline вечір & 5 & & 2 \\
\hline виставка & 1 & & \\
\hline відвідання & 1 & & 1 \\
\hline відкриття & 16 & 1 & 4 \\
\hline візит & & & 1 \\
\hline вшанування & & & 1 \\
\hline дебати & 2 & 2 & 6 \\
\hline дискусія & & & 1 \\
\hline засідання & 31 & 29 & 26 \\
\hline захід & & 4 & 6 \\
\hline заява для преси & & & 1 \\
\hline зібрання, збори, збір & 2 & 9 & 3 \\
\hline з'їзд & 6 & 1 & 2 \\
\hline зустріч & 29 & 10 & 15 \\
\hline інтронізація & & & 1 \\
\hline конвокація & & & 1 \\
\hline конгрес & & & 1 \\
\hline консультації & 2 & & \\
\hline конференція & 4 & 6 & 9 \\
\hline круглий стіл & 4 & & 1 \\
\hline літургія & & & 1 \\
\hline марш & & & 1 \\
\hline мітинг & 3 & & \\
\hline молитва & & & 1 \\
\hline молитовний сніданок & & & 2 \\
\hline нагородження & 1 & & \\
\hline нарада & 5 & 2 & 2 \\
\hline обід & 1 & & \\
\hline парад & & & 4 \\
\hline переговори & 1 & & 2 \\
\hline представлення & 1 & & 1 \\
\hline презентація & & 1 & 2 \\
\hline прийом, прийняття & 3 & & 1 \\
\hline проща & 1 & & 1 \\
\hline реквієм & & & 1 \\
\hline саміт & 5 & 2 & 3 \\
\hline святкування & 1 & & \\
\hline сегмент & & & 1 \\
\hline сесія & 2 & 3 & 2 \\
\hline симпозіум & & 1 & \\
\hline слухання & 2 & 1 & \\
\hline coбop & & & 1 \\
\hline урочистості & 7 & 11 & 4 \\
\hline \multicolumn{2}{|l|}{ урок мужності } & & 1 \\
\hline форум & 8 & 1 & 6 \\
\hline церемонія & 12 & 7 & 29 \\
\hline Усього форматів заходів & 158 & 92 & 151 \\
\hline $\begin{array}{l}\text { Усього форматів заходів - } \\
\text { у відсотках до кількості промов }\end{array}$ & $46,6 \%$ & $40,3 \%$ & $52,2 \%$ \\
\hline Усього типів форматів заходів & 29 & 18 & 39 \\
\hline
\end{tabular}


Отже, найбільше вказівок про формат заходів бачимо у Порошенка; Ющенко та Янукович за цими показниками мають менший відсоток. Тим не менш, за унікальністю форматів Порошенко та Ющенко значно випереджають Януковича, що, знову ж таки, свідчить про більш урізноманітнену комунікацію із суспільством та його інститутами, намагання створювати нові заходи для такої комунікації.

Аудиторії промов

Ще один параметр, що має свідчити про різний підхід до комунікації, - аудиторії, до яких у своїх промовах зверталися президенти. Результати можна побачити у табл. 4.

Таблиця 4

Аудиторії промов президентів України

\begin{tabular}{|l|c|c|c|}
\hline & Ющенко & Янукович & Порошенко \\
\hline ВР & 23 & 10 & 17 \\
\hline дорадчі органи & 2 & 3 & 7 \\
\hline міністри & 7 & 4 & 2 \\
\hline місцева влада, ОДА & 6 & - & 1 \\
\hline РНБО & 3 & 1 & 4 \\
\hline СБУ, МВС, прокуратура, судді, НАБУ & 5 & 6 & 10 \\
\hline зСу, ВМС & 2 & 1 & 6 \\
\hline дипломати & 7 & 2 & 3 \\
\hline партія & 3 & 1 & - \\
\hline міжн.інститути & 29 & 12 & 19 \\
\hline укр.народ, українці за кордоном & 26 & 23 & 23 \\
\hline освітяни, лікарі & 6 & 3 & 7 \\
\hline учасники & 9 & 3 & 3 \\
\hline релігійні інститути, діячі, віруючі & 6 & - & 3 \\
\hline музей, театр & 3 & 1 & 7 \\
\hline зМІ & 10 & 3 & 1 \\
\hline бізнес & 4 & 2 & 119 \\
\hline інше & 1 & 1 & $41,1 \%$ \\
\hline усього & 152 & 76 & \\
\hline усього \% & $44,8 \%$ & $33,3 \%$ & \\
\hline
\end{tabular}

У цій таблиці маємо деякі спільні моменти для трьох президентів - приміром, звернення до народу - 3-поміж найбільш популярних, тим не менш, як Ющенко, так і Порошенко адресували свої промови й українцям за кордоном, Янукович звертався тільки до внутрішньої аудиторії. Також найбільш часто зустрічалися звернення до різноманітних міжнародних інститутів (ПАРС, ООН та ін.), тим не менш, $є$ певне відставання за цим показником у Януковича. Показовою також є кількість згадок Верховної Ради у Ющенка, адже під час його президентського терміну перемогу на парламентських виборах 2006 року здобула опозиційна до нього Партія регіонів. Тим не менш, український народ, міжнародні інститути та Верховна Рада входять до трьох найбільш популярних аудиторій звернень трьох президентів, різними є лише співвідношення.

Щодо решти позицій, для Ющенка притаманна увага до журналістів, виконавчої та місцевої влади. Це має свідчити про намагання президента налагодити комунікацію на всіх рівнях, відкритість президента, у тому числі до ЗМІ. У Януковича на четвертій позиції силові структури та виконавча влада. В принципі, він приділяв увагу силовим відомствам упродовж усього свого терміну, і одне 3 перших його звернень також адресувалося МВС, що може свідчити про авторитарність режиму, тим не менш, лише згадок цих структур для цього не достатньо. До того ж, силові структури також на четвертому місці для Порошенка. При цьому частина згадок присвячена саме реформуванню цих органів, чотири рази було згадане НАБУ, одного разу - поліція. Дорадчі органи, освітяни та журналісти посідають п’яту позицію найбільш популярних аудиторій Порошенка, що також свідчить про більш динамічну комунікацію.

За загальним числом звернень до різноманітних аудиторій очевидним є відставання Януковича за цим показником й більша кількість згадок різноманітних інститутів та суспільних груп у назвах промов Порошенка та Ющенка. Тож ми не бачимо різниці щодо найбільш популярних аудиторій, проте у даному випадку більш диверсифікований підхід до вибору реципієнтів знаходимо у політиків, за часів яких Україна оцінювала вищі оцінки за демократичними показниками.

Географія промов

Виходячи з різних політичних регіональних орієнтацій президентів, знаходимо також і розходження у згадках різних країн (табл. 5). 
Згадки географічних назв у назвах промов президентів

\begin{tabular}{|c|c|c|c|c|c|c|c|c|c|c|c|}
\hline & Ющ. & Ян. & Пор. & & Юu. & Ян. & Пор. & & Юu. & ян. & Пор. \\
\hline \multicolumn{4}{|l|}{ Країни ЄС, Європа } & \multicolumn{4}{|l|}{ колишня СНД } & \multicolumn{4}{|c|}{ Регіони України } \\
\hline Бельгія & & & 1 & Грузія & 4 & 1 & & Донецьк & 3 & 2 & 2 \\
\hline Великобританія & 1 & & 1 & Казахстан & 2 & & & Тернопіль & 1 & & 1 \\
\hline Греція & & 1 & & Молдова & 2 & & & Київ & 2 & 6 & 7 \\
\hline Данія & 1 & & & $P \Phi$ & 6 & 3 & 1 & Крим & 4 & 6 & 6 \\
\hline Латвія & & 1 & & Таджикистан & & 1 & & Львів & 7 & & 2 \\
\hline Литва & 2 & & & Туркменистан & & 1 & & Одеса & 1 & & 1 \\
\hline Нідерланди & & & 1 & СНД & & 3 & & Рівне & 1 & & \\
\hline Німеччина & 1 & 1 & 5 & $\begin{array}{l}\text { колишня СНД } \\
\text { усього }\end{array}$ & 14 & 9 & 1 & Дніпро & & 2 & \\
\hline Польща & 8 & & 4 & \multicolumn{4}{|c|}{ Азія та Близький Схід } & Черкаси & & 1 & \\
\hline Угорщина & 1 & & & Афганістан & 1 & & 1 & Харків & & & 1 \\
\hline Франція & 1 & & & Ізраїль & 2 & & & Донбас & & & 2 \\
\hline Хорватія & 1 & & & Індія & & 1 & & Чернігів & & & 1 \\
\hline Чехія & 1 & & & Малайзія & & & 2 & $\begin{array}{l}\text { регіони } \\
\text { усього }\end{array}$ & 19 & 17 & 23 \\
\hline Швейцарія & 1 & & 1 & Сирія & & & 1 & \multicolumn{4}{|l|}{ Америка } \\
\hline Захід & & & 1 & Туреччина & 2 & 1 & 3 & США & 6 & 2 & 3 \\
\hline $\begin{array}{l}\text { Центральна } \\
\text { Європа }\end{array}$ & & 1 & & Японія & & & 1 & Бразилія & & 2 & \\
\hline Європа & 1 & 2 & 6 & \multirow{5}{*}{$\begin{array}{l}\text { Азія та } \\
\text { Близький Схід } \\
\text { усього }\end{array}$} & \multirow{5}{*}{5} & \multirow{5}{*}{3} & \multirow{5}{*}{8} & Канада & & & 3 \\
\hline$\in C$ & 6 & 2 & 10 & & & & & Мексика & 1 & & \\
\hline $\begin{array}{l}\text { Чорноморський } \\
\text { регіон }\end{array}$ & 1 & & & & & & & \multirow{3}{*}{$\begin{array}{l}\text { Америка } \\
\text { усього }\end{array}$} & \multirow{3}{*}{7} & \multirow{3}{*}{4} & \multirow{3}{*}{6} \\
\hline Балтія & & 1 & & & & & & & & & \\
\hline Європа усього & 25 & 9 & 30 & & & & & & & & \\
\hline
\end{tabular}

Умовні позначення: Ющ. - Ющенко В. А., Ян. - Янукович В. Ф., Пор. - Порошенко П. А.

Як Порошенко, так і Ющенко більше згадують країни ЄС, при цьому для Порошенка характерна найбільша увага до Польщі та Німеччини, Польща також - найбільш згадувана країна для Ющенка. Янукович має менше згадок про ці країни, при цьому жодна 3 них не виокремлюється.

Цікавим також $є$ розподіл уваги до колишніх країн СРСР (без прибалтійських країн). Очевидним є бажання Ющенка вести діалог із РФ, тим не менш, окрім цієї країни він згадує більш проєвропейські країни: Грузію (висловлюючи їй підтримку зокрема й під час Російсько-Грузинської війни у 2008) та Молдову. Із авторитарних країн, окрім РФ, згадано тільки Казахстан.

3-поміж інших країн, як Ющенко, так і Порошенко, приділяють увагу США, проте для останнього однаково важлива Канада.

Орієнтири ж Януковича зовсім інші. Він звертає увагу не тільки на РФ, а й на авторитарні Таджикистан та Туркменістан, при цьому для нього важливим є простір СНД (якщо згадок про Європу та ЄС у нього - 4, то СНД - 3). Також показовою $є$ менша увага до США (порівняно з Ющенком). Решта країн Януковичем згадуються лише одного разу (окрім Бразилії), що також показує його незначну зацікавленість іншими регіонами (окрім СНД).

Щодо регіонів України очевидною є більша регіональна різноманітність, притаманна Порошенку, натомість Ющенко, порівняно із Януковичем та Порошенком, менше згадує про українські регіони. При цьому Янукович має більше згадок про області України, ніж про інші регіони.

Тим не менш, якщо підрахувати кількість згадок різних географічних назв (та їхні відсотки), найбільше цьому приділяє увагу Порошенко. Янукович же програє обидвом.

Тож можемо припустити, що за згадками географічних назв більш авторитарний лідер тяжітиме саме до країн зі схожими режимами, також можемо зафіксувати чи спрогнозувати зміну режиму за зміною «географії» промов: від демократичних до авторитарних (чи навпаки). 
Висновки

Отже, в українському науковому дискурсі промови політиків більше вивчаються з точки зору політичної лінгвістики, при цьому існує певна жанрова невизначеність поняття «промова», не виокремлюються інші жанри прямих звернень до аудиторії, мало вивчаються комунікативні ситуації, за яких промови виголошуються, їхня аудиторна спрямованість. До того ж, для вивчення промов найчастіше застосовуються якісні методи. Використання формалізованих методів дозволяє не тільки зіставляти промови декількох політичних діячів, а також вивчати, як у політичних промовах відображаються прагнення політиків до більш авторитарної / демократичної моделі управління.

Вивчення політичних промов трьох українських президентів якраз і дає змогу прослідкувати, як політичний режим відображається на політичному тексті. Наша гіпотеза про більш інтенсивну комунікацію за демократично орієнтованого політика підтвердилася лише частково (хоча вона працює упорівнянні України з такими авторитарними режимами, як у Білорусі та Казахстані). До того ж, тут мусимо враховувати ймовірне зниження популярності промов порівняно зі зверненнями через соціальні мережі. Також маємо враховувати високу інтенсивність політичного життя України, що «втягує» президента у комунікацію, тому за Януковича ми маємо зниження кількості промов тільки у два перших роки.

Тим не менш, вимірювати зміну режимів (перехід від демократичного до авторитарного і навпаки) можемо через інші показники. Зокрема це більше різноманітне використання піджанрів промов, оскільки, згідно із теорією жанру, жанри зорієнтовано на те, щоб якнайкраще відображати унікальну комунікативну ситуацію. Відтак, якщо комунікативні ситуації повторювані, влада не відчуває потреби урізноманітнити форми спілкування зі своїми аудиторіями. Також коливання режимів відображаються на використанні більш унікальних форматів, у межах яких відбувається спілкування президента із суспільством та його інститутами, та звичайних, а не календарних чи історичних інформаційних приводів. Щодо аудиторій, можемо констатувати наявність однакових найбільш популярних аудиторій для усіх трьох політиків (народ, міжнародні інститути, парламент). Тим не менш, різниця відчувається у різному розподілі уваги до них та у більшій кількості згадок про аудиторії у демократичних лідерів. Географічні преференції дозволяють нам показувати різну спрямованість щодо регіональних утворень, а також зафіксувати більшу увагу до регіонів у межах країни, ніж до зарубіжних країн, та до країн із авторитарними режимами відповідно у авторитарного лідера. При цьому кардинальна зміна «географічних» пріоритетів у промовах дозволяє зафіксувати спрямованість офіційного дискурсу на роз'єднання: «використання інших країн у публічних промовах як загрозу чи союзників України трансформує розкол країни за лініями Схід - Захід, Північ - Південь» [9, с. 28].

Тож, проблема відображення політичного режиму у політичних текстах потребує подальшого вивчення, зокрема, із використанням формальних методів можливе зіставлення політичних текстів, що продукуються різними режимами, а на основі цього подібного зіставлення можливо буде запропонувати як більш широку типологію політичних текстів (зокрема промов), так і політичних режимів у межах категорії «авторитарний»/ «демократичний» режими.

\section{Примімки:}

* Media Sustainability Index (MSI) Explorer. URL: https://www.mediasustainabilityindex.org/

** Freedom in the world. Ukraine. URL: https://freedomhouse.org/report/freedom-world/2014/ukraine

\section{Бібліографічний список:}

1. Баровська А., Коваль І. Архів промов президента як чинник реалізації публічності інституту президентства. Актуальні проблеми державного управління, 2013. № 3. С. 39-44.

2. Гузак А. М. Типологічні особливості вживання прецедентних імен у політичній ораторській промові (на матеріалі промов американских президентів). Одеський лінгвістичний вісник, 2014. № 4. С. 56-59.

3. Заблоцький Ю. В. Аналіз передвиборчих промов кандидатів у президенти США у 2012 році (М. Ромні та Б. Обама). Одеський лінгвістичний вісник, 2015. № 5(1). С. 57-62.

4. Земская Ю., Кузнецова, Е. Спичрайтинг и копирайтинг: филология на службе интегрированных маркетинговых технологий. Филология и человек, 2014. С. 1-6.

5. Казанцева М. С. Спичрайтинг как технология подготовки политических текстов. Бизнес. Общество. Власть, 2010. № 5. С. 25-39.

6. Кльось С. Семантичні особливості функціонування фразеологізмів у політичному дискурсі (на основі промов діячів англійською мовою). Молодь і ринок, 2012. № 1. С. 106-110.

7. Куліш Т. В. Параноїдний стиль в американському політичному дискурсі (на матеріалі промов Джозефа МакКарті). Мовні і концептуальні картини світу, 2014. № 50(1). С. 421-427.

8. Лосєва І. Мовностилістичні ознаки політичних промов. Нова філологія, 2012. № 50. С. 64-66.

9. Мацишина І. В. Формування політичної реальності України. Київ: ТОВ «Твори», 2019. - 376 с.

10. Скрипникова Н. Спичрайтинг в политическом дискурсе (на примере публичных выступлений президента РФ). Язык: история и современность, 2017. № 2. С. 92-100.

11. Тхір М. Б. Новорічна політична промова як жанр публічного виступу (на матеріалі промов американських президентів). Мова і культура, 2011. № 6(14). С. 232-236.

12. Федорченко Л. Спичрайтинг как форма политического консалтинга в современной России. Вестник МГОУ, 2012. № 2. С. 155-161.

13. Холод, О. М. Соціо- та психолінгвістичні маркери імперативів у текстах промов керівників III Рейху як ознаки інмутації соціальної реальності. Психолінгвістика, 2016. № 19(2). С. 122-138. 
14. Худолій А. О. Картина світу американських політиків (на матеріалі промов президентів США). Наукові записки Національного університету "Острозька академія". Серія : Філологічна. 2014. № 46, С. 208-211.

15. Чепкасов А. Супра- и топографематические средства в практике спичрайтинга: на примере текстов выступлений губернатора Кемеровской области. Коммуникативные исследования, 2018. № 3(17), С. 211-225. DOI: $10.25513 / 2413-6182.2018 .3 .211-225$

16. Швецова В. Види судових промов та їх особливості. Науковий вісник Південноукраїнського національного педагогічного університету імені К. Д. Уиинського. Лінгвістичні науки, 2017. № 24. С. 95-100.

17. Bayram F. Ideology and Political Discourse: a Critical Discourse Analysis of Erdogan's Political Speech. Annual Review of Education, Communication and Language Sciences, 2010. №7. C. 23-40.

18. Chang P. Discourse Analysis of President's Bush Speech at Tsinghua University, China. Intercultural Communication Studies, 2007. № 16(1). C. 205-216.

19. Habwe J. H. Discourse analysis of Swahili Political Speeches. Nairobi: University of Nairobi, 1999. 379 p.

20. Murphy J. "Our Mission and Our Moment": George W. Bush and September 11th. Rhetoric and Public Affairs, 2003. № 6(4). C. 607-632.

21. Wang J. A Critical Discourse Analysis of Barack Obama's Speeches. Journal of Language Teaching and Research, 2010. № 1(3). C. 254-261.

\section{References:}

1. Barovs`ka A., and Koval` I. Arxiv promov prezy`denta yak chy`nny`k realizaciyi publichnosti insty`tutu prezy`dentstva. Aktual `ni problemy`derzhavnogo upravlinnya, 2013. No 3. P. 39-44.

2. Guzak A. M. Ty`pologichni osobly`vosti vzhy`vannya precedentny`x imen u polity`chnij orators`kij promovi (na materiali promov amery`kansky`x prezy`dentiv). Odes `ky j lingvisty`chny j visny $k$, 2014. No 4. P. 56-59.

3. Zablocz 'ky`j Y. V. Analiz peredvy`borchy`x promov kandy`dativ u prezy`denty` SShA u 2012 roci (M. Romni ta B. Obama). Odes `ky $j$ lingvisty chny $j$ visny $k$, 2015. No 5(1). P. 57-62.

4. Zemskaja J., and Kuznecova, E. Spichrajting i kopirajting: filologija na sluzhbe integrirovannyh marketingovyh tehnologij. Filologija i chelovek, 2014. P. 1-6.

5. Kazanceva M. S. Spichrajting kak tehnologija podgotovki politicheskih tekstov. Biznes. Obshhestvo. Vlast', 2010. No 5. P. 25-39.

6. Kl`os` S. Semanty`chni osobly`vosti funkcionuvannya frazeologizmiv u polity`chnomu dy`skursi (na osnovi promov diyachiv anglijs`koyu movoyu). Molod`i ry`nok, 2012. No 1. P. 106-110.

7. Kulish T. V. Paranoyidny`j sty`l`v amery`kans`komu polity`chnomu dy`skursi (na materiali promov Dzhozefa MakKarti). Movni i konceptual 'ni karty ‘ny`svitu, 2014. No 50(1). P. 421-427.

8. Losyeva I. Movnosty`listy`chni oznaky` polity`chny`x promov. Nova filologiya, 2012. P. 64-66.

9. Macy`shy`na I. V. Formuvannya polity`chnoyi real`nosti Ukrayiny`. Ky`yiv: TOV Tvory`, 2019. - 376 p.

10. Skripnikova N. Spichrajting v politicheskom diskurse (na primere publichnyh vystuplenij prezidenta RF). Jazyk: istorija i sovremennost', 2017. No 2. P. 92-100.

11. Txir M. B. Novorichna polity`chna promova yak zhanr publichnogo vy`stupu (na materiali promov amery`kans`ky`x prezy`dentiv). Mova i kul 'tura, 2011. No 6(14). P. 232-236.

12. Fedorchenko, L. Spichrajting kak forma politicheskogo konsaltinga v sovremennoj Rossii. Vestnik MGOU, 2012. No 2. P. 155-161.

13. Xolod, O. M. Socio- ta psy`xolingvisty`chni markery` imperaty`viv u tekstax promov kerivny`kiv III Rejxu yak oznaky` inmutaciyi social ’noyi real'nosti. Psy`holingvisty `ka, 2016. No 19(2). P. 122-138.

14. Xudolij A. O. Karty`na svitu amery`kans`ky`x polity`kiv (na materiali promov prezy`dentiv SShA). Naukovi zapy `sky Nacional ’nogo universy ‘tetu "Ostroz 'ka akademiya". Seriya : Filologichna. 2014. No 46, P. 208-211.

15. Chepkasov, A. Supra- i topografematicheskie sredstva v praktike spichrajtinga: na primere tekstov vystuplenij gubernatora Kemerovskoj oblasti. Kommunikativnye issledovanija, 2018. No 3(17), P. 211-225. DOI: 10.25513/24136182.2018.3.211-225

16. Shveczova V. Vy`dy` sudovy`x promov ta yix osobly`vosti. Naukovy`j visny`k Pivdennoukrayins `kogo nacional `nogo pedagogichnogo universy`tetu imeni K. D. Ushy`ns`kogo. Lingvisty`chni nauky', 2017. No 24. P. 95-100.

17. Bayram F. Ideology and Political Discourse: a Critical Discourse Analysis of Erdogan's Political Speech. Annual Review of Education, Communication and Language Sciences, 2010. №7. C. 23-40.

18. Chang P. Discourse Analysis of President's Bush Speech at Tsinghua University, China. Intercultural Communication Studies, 2007. № 16(1). C. 205-216.

19. Habwe J. H. Discourse analysis of Swahili Political Speeches. Nairobi: University of Nairobi, 1999. 379 p.

20. Murphy J. "Our Mission and Our Moment": George W. Bush and September 11th. Rhetoric and Public Affairs, 2003. № 6(4). C. 607-632.

21. Wang J. A Critical Discourse Analysis of Barack Obama's Speeches. Journal of Language Teaching and Research, 2010. № 1(3). C. 254-261. 